\title{
A Rapid Method for Cannabis Species Determination by DNA Sequencing
}

\author{
David A. Lightfoot ${ }^{1,2, *}$, Winston C. Throgmorton ${ }^{3}$, and Colton Johnson ${ }^{3}$
}

${ }^{1}$ Genome and Agricultural Biotechnology LLC, Carbondale, IL 62901, USA; ${ }^{2}$ PO Box 0312 , Carbondale, IL 62903, USA; ${ }^{3}$ Throgmorton Attorney at Law, 304 N. Monroe Street, Marion, IL, USA. Tel: (61 8) 993-5379.

Received: September 19, 2016 / Accepted: October 9, 2016

\begin{abstract}
Determination of species within the genus Cannabis has important legal medical and social implications. Recent genome sequencing has shown that the genomes of $C$. sativa (recreational marijuana and hemp), $C$. indica (medical marijuana) and $C$. ruderalis (feral marijuana) can all be distinguished. However, hybridization among the species has occurred with widely varying outcomes in the percent of genome transmitted. The aim here was to determine if a simple assay based on the DNA sequence of ITS2 could be used to distinguish among species. Using sequences at GenBank as a reference eighteen plant samples were sequenced and shown to be identical to $C$. indica sequence and different from $C$. sativa and $C$. ruderalis at 4 positions within the 255 rRNA gene. This result and the geographic separation of the centers of genetic diversity argues strongly for polytypic origins of the 3 species. Analysis of interspecific hybrids sequences at GenBank suggested only the $C$. indica allele is transmitted preferentially. Finally, a SNP within the ITS could be used to distinguish two types within the eighteen plants. Therefore this simple genetic test can be used for rapid plant identification and to assist in strain identification.
\end{abstract}

\section{Introduction}

Internal transcribed spacer (ITS) refers to the spacer DNA (non-coding DNA) situated between the small-subunit ribosomal RNA (rRNA) and large-subunit rRNA genes in the chromosome (Coleman, 2007). There are two ITS's in eukaryotes; ITS1 is located between $18 \mathrm{~S}$ and 5.8S rRNA genes, while ITS2 is between $5.8 \mathrm{~S}$ and $25 \mathrm{~S}$ (in plants) rRNA genes.

Sequence comparison of the ITS region is widely used in taxonomy and molecular phylogeny because it a) is easy to amplify even from small quantities of DNA (due to the high copy number of rRNA genes), and b) has a high degree of variation even between closely related species (Coleman, 2007; Shultz et al., 2006). The success rates for using the ITS2 region to identify dicotyledons plants was $76.1 \%$, at the species level (Kress et al., 2006; Yao et al., 2010).

The ITS region is the most widely sequenced DNA region in molecular ecology of plants and has been recommended among the universal barcode sequences (Kress et al., 2006; Yao et al., 2010) It has typically been most useful for molecular systematics at the species level, and even within species (e.g., to identify geographic races, varieties and ancestoral types). The standard ITS1 and ITS4 primers are used by most labs (White et al., 1990).

\footnotetext{
*Corresponding author: ga4082@siu.edu
}

ATLOS Publishing, LP
This is an Open Access article distributed under the terms of the Creative Commons Attribution License (http://creativecommons.org/licenses/by/3.0/), which permits unrestricted use, distribution, and reproduction in any medium, provided the original work is properly cited. 
Determination of species within the genus Cannabis has important legal medical and social implications. However, the literature to date has been confused on some key concepts because of the remarkable amount of genetic variation and phenotypic plasticity within the genus (Schultes et al., 1974; Sawler et al., 2015). Selection, cultivation, hybridizations by both man and nature, crop abandonment and feral growth have all combined to confuse the identities and origins of the four crops, C. sativa (recreational marijuana and hemp), C. indica (medical marijuana) and C. ruderalis (feral marijuana). However, it seems possible they had polytypic origin since their centers of wild plant genetic diversity differ, East Asia, India and Russia for the 3 species respecctively.

Recent genome sequencing has shown that the genomes of C. sativa (recreational marijuana and hemp), C. indica (medical marijuana) and C. ruderalis (feral marijuana) can all be distinguished (Sawler e al., 2015). However, hybridization among the species has occurred with widely varying outcomes in the percent of genome transmitted. Observations of phenotypes suggest the $\mathrm{C}$. indica type is dominant with preferential transmission of its alleles in known interspecific hybrids. Preferential transmission of alleles is widely observed in interspecific crosses with one parent being dominant in all crosses made (Guo et al., 1990).

Here is described a simple and rapid genetic test that distinguishes

\section{Materials and Methods}

\section{Sampling}

On February 10, 2015 eighteen samples from eighteen plants were collected by Prof. David A Lightfoot, Principal Scientist, GAAB-LLC, Carbondale, IL 62901, USA. An analysis of the samples species identity had been requested. They were provided as follows.

\section{DNA Extractions}

All eighteen samples were handled in the same way. Gloves were worn by Dr. Lightfoot throughout. All vials and plastic ware were new and had been sterilized. The Promega GenewizTM kit was used for purifications. The kit was new.

\section{PCR Conditions}

Following White, et al (1990), primers were: 5'-AGC CGC CTT CAT ATA TCT GCT T -3' ITS 1 - forward; 5'-TCC TCC GCT TAT TGA TAT GC -3' ITS4 - reverse.

Polymerase chain reaction (PCR) was performed using 25, 50 or $75 \mathrm{ng}$ of genomic DNA, $225 \mu \mathrm{l}$ of SuperMix High Fidelity Enzyme (GibcoBRL, Grand Island, NY), $5 \mathrm{Hl} \mathrm{H}_{2} \mathrm{O}, 5 \mu \mathrm{l}$ ITS 1 -Forward, and $5 \mu \mathrm{l}$ ITS4-reverse in a total volume of $20 \mu \mathrm{l}$. Cycling conditions were: $95^{\circ} \mathrm{C}$ for $1 \mathrm{~min}$, then $45^{\circ} \mathrm{C}$ for $1 \mathrm{~min}$, then $68^{\circ} \mathrm{C}$ for $1 \mathrm{~min}$ for 35 cycles finishing with a and $4^{\circ} \mathrm{C}$ hold. The PCR products were prepared for Sanger sequencing reactions by alkaline phosphatase and exonuclease 1 treatment.

\section{DNA Sequencing}

The DNA in samples sent for forward DNA sequencing using services provided by GeneWiz Inc. (Plainsfield, NJ, USA) using the amplification primer ITS1. DNA sequences were obtained that were found in the gene data repository at NCBI. The sequences were aligned with reference sequences for $C$. sativa (record identifier FJ572045.1) and C. indica (record identifier KC292629.1) found at NCBI by BLAST searching. A new sequence for $C$. indica was deposited at GenBank as accession number KX980526.

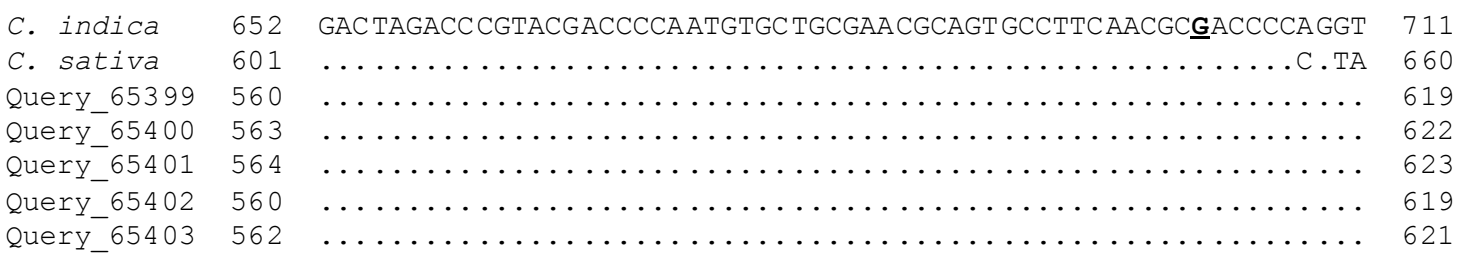

Figure 1. A complex rearrangement in the $25 \mathrm{~S}$ rRNA gene distinguishes $\mathrm{C}$. indica from $\mathrm{C}$. sativa.

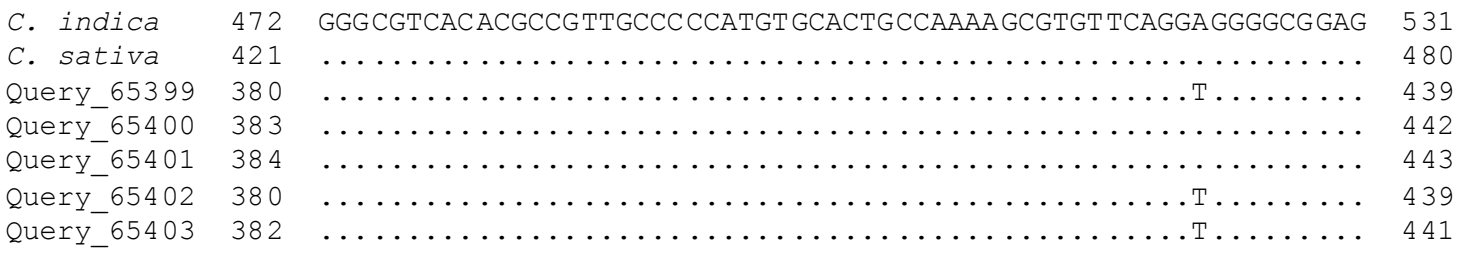

Figure 2. A SNP in the ITS2 region identified two strains of C. indica. 
